\title{
The Characteristics and Management Practices of Public Toilets
}

\section{in Wa, Ghana}

\author{
Christian Ahuma-Smith ${ }^{1 *}$ Samson Bavuno ${ }^{2}$ George Okyere Dokyi ${ }^{1}$ \\ 1. Wa Polytechnic, Department of Civil Engineering, P. O. Box 553, Wa - UW/ R, Ghana \\ 2. Wa Polytechnic, Department of Building Technology and Estate Management, P. O. Box 553, Wa- \\ UW/R, Ghana \\ *E-mail of the corresponding author: chrisonsmith@gmail.com
}

\begin{abstract}
Public toilets are an important sanitation option that responds to the sanitary needs of the urban poor and transient populace. This research, therefore seeks to explore the characteristics and, the operation and maintenance practices of public toilets in Wa Township. All the public toilet facilities in Wa were purposively selected and considered under this study. The use of qquestionnaires, survey and key informant interviews were employed to solicit the required data that were analysed to generate the desired outcomes. The results indicate that sanitary conditions of most public toilet facilities were in a sorry state and need urgent improvement. The findings of the study further suggested that poor supervision, lack of regular and adequate on-site water supply, lack of training on toilet management and maintenance has contributed to the sorry state of most toilet facilities. In line with the findings, the study recommends the resourcing and tooling of Environmental Health Officers of the Municipal Assembly for effective and intensive monitoring of the public toilet facilities to ensure operators comply with the guidelines for the provision, operation, and maintenance of public toilets The study further recommends the establishment of a sludge treatment plant or a dedicated and regulated site for the dumping of faecal sludge.
\end{abstract}

Key words Public Toilet, Faecal, Sludge, Management

DOI: $10.7176 / \mathrm{CER} / 12-6-08$

Publication date:June $30^{\text {th }} 2020$

\section{Intorduction}

The benefits of improved sanitation encompass the attainment of excellent public health, promoting dignity, and potential recovery of water, renewable energy, and nutrients from faecal waste (WHO, 2018). The World Health Organization and United Nations Children's Fund (WHO/UNICEF) Joint Monitoring Programme for Water Supply, Sanitation, and Hygiene (JMP, 2019) defines improved sanitation as sanitation facilities that are designed to hygienically separate human excreta from human contact. Wet sanitation technologies such as flush and pourflush toilets connecting to sewers, septic tanks or pit latrines, and dry sanitation technologies, such as dry pit latrines with slabs and composting toilets are considered as improved sanitation facilities. Also, JMP further classifies improved facilities shared by more than one household as limited service sanitation. Consequently, shared facilities such as compound toilets, community toilets, public toilets are therefore not acceptable forms of safely managed sanitation. The JMP (2019), states that besides the possible upsurge in exposure to health risks, shared facilities adversely affect the dignity, privacy, and safety of vulnerable adults and young people. Nonetheless, JMP acknowledges that shared sanitation is an important sanitation option that responds to the need for increased sanitation access for the urban poor. McGinnis et al. (2019), also argues that, for a significant number of poor urban dwellers, a shared facility is the only alternative to ending open defecation, it as well provides them with the opportunity to move up the sanitation ladder. According to Cardone et al. (2018), public toilet refers to a shared facility built-in public or commercial areas such as markets and lorry terminals for the transient populace. The public toilet provides travelers and people away-from-home with the opportunity to attend to their sanitary needs.

Public toilets contribute to curbing open defecation amongst people away-from-home thus improving environmental quality and general wellbeing. According to Greed, as cited by Oyinloye and Oluwadare (2015), public toilets contribute to the creation of sustainable, accessible, and inclusive cities. Osumanu and Kosoe (2013), also indicated that public toilets serve the interest of public health by improving general sanitation especially in low-income neighbourhoods and commercial centres. The absence of public toilets may compel people who are out of their homes to suppress the urge to defecate or urinate. According to Ruiz and Kaiser (2017), suppressing faece or urine for long periods may trigger or aggravate health conditions such as skin maceration, urinary tract infections, and decubitus amongst others. 
In Ghana, public toilets are an integral part of urban life (Okechukwu et al., 2012; Ayee and Crook, 2003). Depending on its location, a public toilet may serve transient or residential users or both users. According to the Ghana Statistical Service (GSS, 2012), 34.6\% of households in Ghana make regular/daily use of public toilets thus, making it the most widely used toilet facility in Ghana. The reliance on public toilets by residents stems from the inability of local government agencies to enforce or prosecute offenders for incessantly flouting the bye-laws on the provision of residential/household toilet facilities. Other driving factors attributable to the prevalence of or reliance on public toilets include insecure tenure, space constraints, absence of affordable improved sanitation options and low-level of awareness of the importance of sanitation (Osumanu et al., 2019; Peprah et al. 2015; Nelson et al., 2014). Cognizant of the hazards fronted by insanitary conditions or defectively maintained toilet facilities, the government of Ghana through the Ministry of Local Government and Rural Development (MLGRD) introduced guidelines to provide sound and effective regime for the operation and maintenance of public toilets. The guidelines address multiple aspects of public toilets including design considerations, construction options, and rehabilitation, management structure and staffing, operation and maintenance tasks (MLGRD, 2003).

Wa Municipality, the capital of the Upper West Region of Ghana, has $44.4 \%$ of households in the urban setting relying on public toilets to meet their sanitary needs (GSS, 2014). Owing to the large number of households relying on public toilets and, the significant role played by these facilities, it is only prudent to assess the prevailing conditions of public toilets in the urban setting of the Municipality. Specifically, this study seeks to explore the characteristics and, the operation and maintenance practices of public toilets in Wa Township.

\section{Methods and Material 2.1 Study Setting}

Wa is a town situated within the Wa Municipality in the Southern part of the Upper West Region of the NorthWestern part of Ghana. It doubles as the administrative capital of Wa Municipality and the Upper West Region. It lays on latitudes $10^{\circ} 03^{\prime} 38.48^{\prime \prime} \mathrm{N}$ and longitudes $-2^{\circ} 30^{\prime} 6.91^{\prime \prime} \mathrm{W}$. The Municipality is reported as having an urban population growth rate of $4 \%$, with Wa town accounting for an urbanized population of 71,051 representing $66.3 \%$ of the entire population of the Municipality (GSS, 2012). The heavy concentration of the population in Wa town is attributable to the high level of facilities such as health, education, finance, transportation, commerce amongst others. Wa Municipality shares administrative boundaries with the Nadowli-Kaleo District to the North, Wa East District to the East and South boundaries, and the Wa West District to the West and South.

\subsubsection{Method}

Both quantitative and qualitative approaches were employed consideration the data demands of the study. The data gathered from the field was considered as primary data and documented sources as secondary data. Primary data was collected through the administration of questionnaires and field observation of all the forty-two public sanitary sites. Semi-structured interviews, surveys, and observation were the major techniques of data collection methods. Secondary data was gathered from sources such as published articles from journals and books on the subject under study to augment the available primary data.

Forty-two respondents (representing facility attendants) were purposively selected and interviewed using the questionnaires. The survey involved the use of interview schedules, especially for the illiterate respondents. This technique offered the respondents the opportunity to express themselves as much as possible because most of the questions were open-ended. The administration of the questionnaires, observation, inspection, and the interview schedule was carried out mostly early in the morning and afternoons. Through field visits and observation, the management and operational activities were observed and documented and, some still pictures were also taken. The data gathered from the field study were edited to ensure the questionnaire and interview schedules were properly completed and contained accurate information. The data obtained in quantitative form was transformed into frequency counts, percentages, and cross-tabulations for purposes of analyses and interpretation. Qualitative data were analysed manually using content analysis.

\section{Results and Discussion \\ 3.1 Characteristics of public toilet facilities}

The study revealed a total of 44 public toilets (figure 1), however, only 42 were functional, serving both the transient and residential populace. One of the other two facilitie had its roof structure ripped off whilst the other was under renovation. The facilities were mostly $(n=38)$ sited within the low-income neighbourhoods with a few $(n=6)$ within the main commercial center. This observation is in line with a recent finding of Osumanu et al. 
(2019) which noted that $49.8 \%$ of households in Wa had no form of residential toilet facility and therefore resorted to public toilets or practiced open defecation. Typical of all low-income urban neighbourhoods, lack of space, poverty, insecure tenure, high population rates and, dilapidated or poor housing units impedes the provision of residential toilet facilities. The Local Government Act 1993 (Act 462), therefore, mandates the Municipal and District Assemblies (MMDAs) to provide sanitary facilities for such neighbourhoods for safe and hygienic excreta disposal to ensure a healthy environment and disease prevention. Thus the commonness of these facilities within the low-income neighbourhoods. The commercial area is the focal point for commerce and the location for the major transport terminal. It is, therefore, imperative to provide the area with toilets facilities to serve the transient populace and those residing within the vicinity.

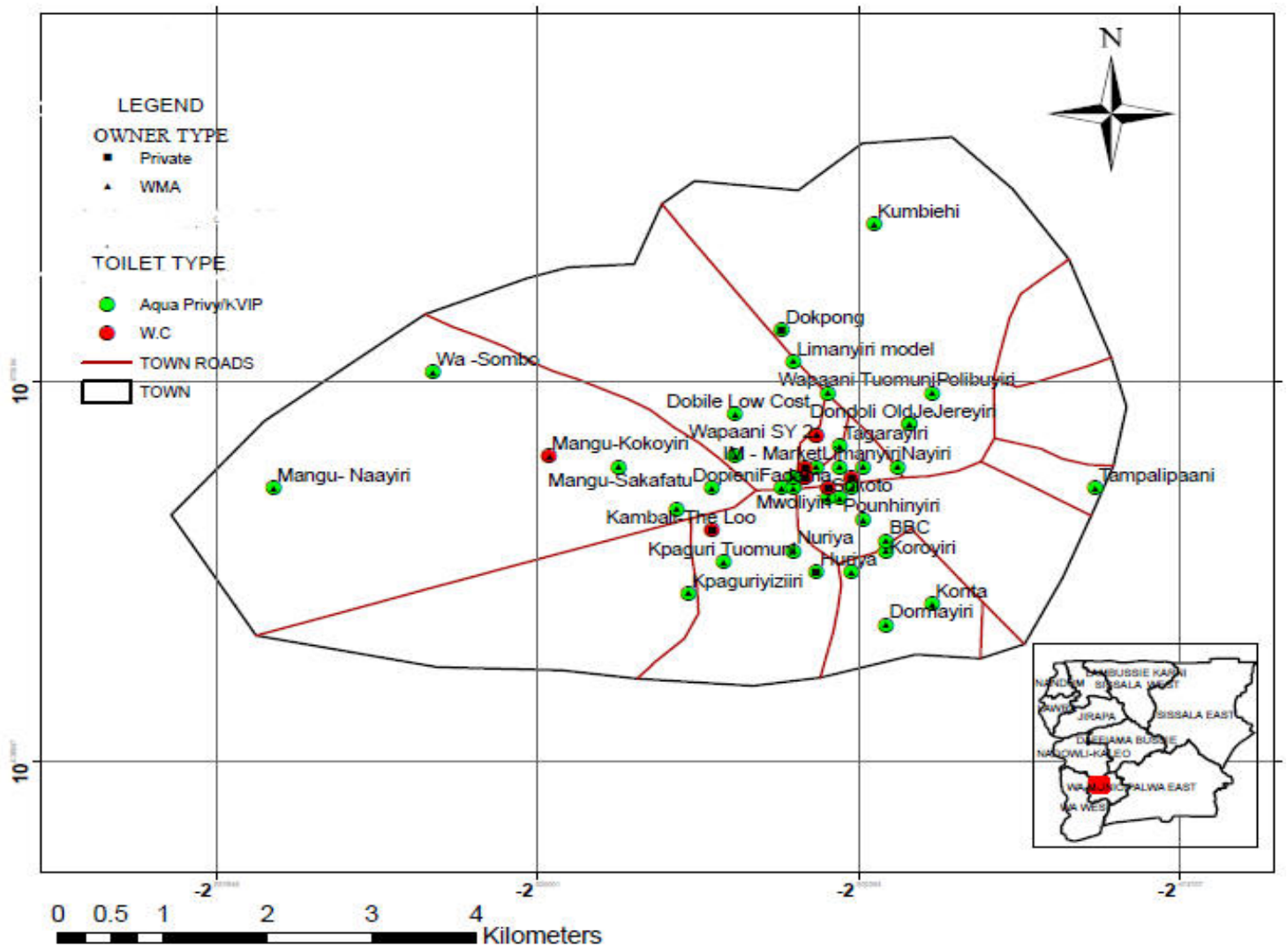

Figure 1: Public toilet locations within Wa township

Three sanitary technologies identified during the study included aqua privy, water closet (WC) and ventilated improved pit (VIP) latrine. The predominant technology was aqua privy (63.6\%). It was very unexpected to know that aqua privy was the leading sanitary technology in Wa township. This is because, this system, according to Reed (2011), is unsuitable for areas where water supply is limited. Recent studies by Darimani et al., 2020; Arthur, 2017; and Amoah and Yahaya, 2013, have all, however, shown that water coverage and accessibility is not encouraging within Wa Municipality. VIP constituted $20.5 \%$ of the sanitary facilities. Unlike the aqua privy, the VIP does not require water to effectively function so are appropriate in areas where there is no adequate and regular water supply. The third technology, which was WC constituted 15.9\% (Table 1).

The capacities of the public sanitary facilities in the study area ranged between 10-cubicles and 28-cubicles per facility. The cubicles of the VIP and aqua privy facilities ranged between 10-cubicles and 24-cubicles whereas, the WC facilities ranged between 10-cubicles and 28-cubicles per facility. Each facility was segmented into male and female sections to offer privacy to and allow both sexes to use the same facility concurrently. High cubicles number disallowed delays and long queues at the facility. 
Table 1: Types of sanitary facilities

$\begin{array}{lcc}\text { Type of Sanitary Facility } & \text { Frequency } & \text { Percentage } \\ \text { Aqua Privy } & 27 & 61.4 \\ \text { VIP } & 10 & 22.7 \\ \text { WC } & 7 & 15.9 \\ \text { Total } & 44 & 100\end{array}$

It was observed that gaps existed between existing aqua privy in the study area and conventional technical design guidelines for aqua privy. According to Reed (2011), the settlement tank of an aqua privy must be watertight to maintain a constant liquid level, also there must be an outlet leading to a soakaway or drainage field, a vent pipe with a securely fitted fly screen and, a drop pipe (100-150 mm diameter) for excreta passage attached to the base of each squatting hole, extending about $75 \mathrm{~mm}$ minimum below the water level in the settlement tank, thus providing and maintaining a water seal to control odour and flies.

Conversely, all the settlement tanks which were directly beneath the latrine slabs functioned as cesspools, basically storing excreta for removal and disposal. This is because soakaways or drainage fields were not part of the initial design and construction (figure 1). This finding corroborates with the report of MLGRD (2003) that almost all aqua privy public toilets facilities either have no or completely clogged drainage field. A considerable number $(85.7 \%)$ of tanks were also found to have developed deep cracks or had parts broken off, thereby rendering such tanks as non-watertight. Such tanks had no or very low water level owing to seepage.

It is also pertinent to note that only $11.1 \%$ of the facilities had a drop-pipe attached to the squatting hole. All three facilities had simple wooden plungers for displacing solid material from the drop-pipe. The remaining $88.9 \%$ facilities had no drop pipes attached to the base of the squatting holes (figure 2). The non-availability of drop pipes and no or low level of water in the tanks made the provision and maintenance of a seal to curbs flies and odour nuisance non-attainable. Also, it can be observed that $11.1 \%$ (figure 2) of the facilities had no vent pipes although vent holes were visibly seen in the tank slab. The absence of the pipes may be ascribed to poor workmanship, poor quality of the pipe, or damage by elements of the weather, however, this study was unable to ascertain the veracity or otherwise. The remaining $88.9 \%$ sampled facilities had vent pipes. However, vent pipes of 9 facilities were found to have been partly damaged. The damages ranged from varying degrees of holes in pipes to reduction in height of pipe due to breakage.

Although $74.1 \%$ of the facilities had screens fitted to vent pipes, these screens were, however, found to have been compromised and could not be referred to as fly screens. It was observed that 3 of the facilities had their meshes which was supposed to serve as fly screens either completely clogged by cobweb and dust or torn due to rust and, 17 other facilities had their screens replaced with vent caps. The gaps on the sides of the vent cap were large enough to all flies to either enter or exit the tanks. A cursory look at the exposed ends of the vent pipes of the other 4 facilities without flyscreen showed that the screens were one time present. The analysis of the study further revealed that $81.5 \%$ of the facilities had the inspection covers tanks either partly not available or broken.

According to Reed (2011), defective vent pipes and fly screens, and the absence of water seals are recipes for the breeding of flies in tanks and odour entering the cubicles respectively. It was observed that most users, especially males, took off their clothes before entering the facility to prevent them from smelling. Furthermore, flies which are transmitters of pathogens were visibly present in cubicles and around vent pipes. This affirms a recent study by Obeng et al. (2019c), where they stated that, flies in the environment are usually attracted to the odour emanating from vent pipes.

VIP latrines constituted $22.7 \%$ of the public toilets in the study area (Table 1 ). This sanitary technology which is an improved version of the traditional pit latrine eliminates odour and insect proliferation from the cubicles of the facility. Thus, ventilation and fly control components are essential features for effective operation. Usually, flies migrate towards light therefore, effective control of light within the superstructure and an upright vent pipe with a securely fitted fly screen restraints the movement of flies (Reed, 2014). Except for 2 (20\%) of VIP facilities not having vent pipes, the remaining $8(80 \%)$ had vent pipes fitted to latrine slabs (figure 3$)$. However, the study revealed that all $(100 \%)$ of the vent pipes failed to satisfy the required diameter specification. 


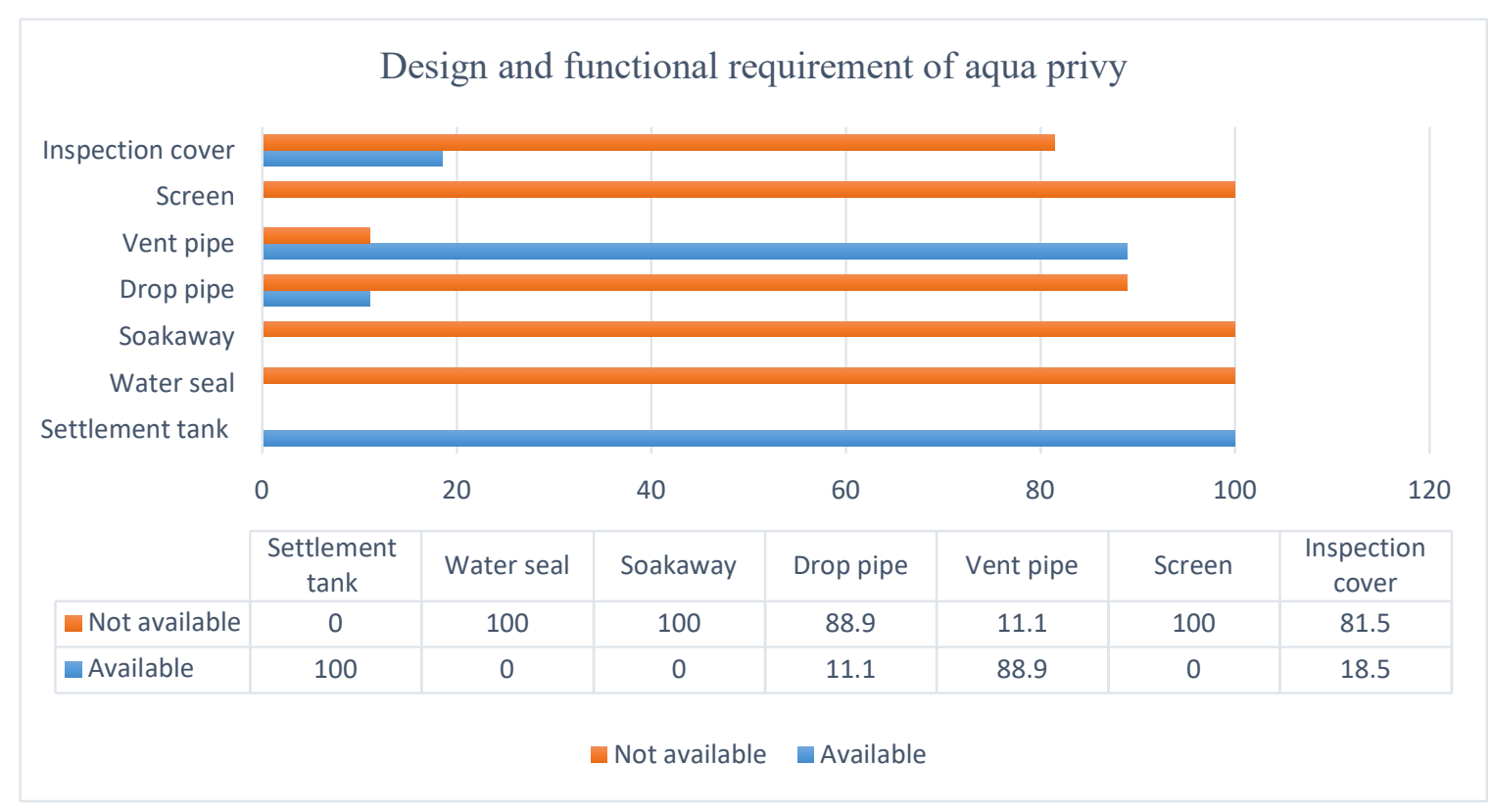

Figure 2: Design and functional requirement of an aqua privy

To allow free passage of air within the facility, Reed (2014), argues that the diameter of the ventilation pipe should be large enough, at least $150 \mathrm{~mm}$ in diameter for pipes with smooth inner walls or else $200-250 \mathrm{~mm}$ diameter pipes will be appropriate. It is important to state that, all (aqua privy, VIP, and WC) the public sanitary facilities in the study were fitted with $100 \mathrm{~mm}$ diameter vent pipes. This confirms earlier studies (Obeng et al., 2019a, 2019c), that suggested that the use of $100 \mathrm{~mm}$ diameter pipes appeared to be the preferred choice of vent pipes for the latrine in Ghana.

For an efficient output in controlling fly nuisance, the superstructure of VIP latrines needs to be suitably dark (Reed, 2014), besides, the vent pipes should be securely fitted with fly screen to obstruct the movement of flies but allow malodorous air to exit the pit through the vent pipe (Obeng et al., 2019c). From figure 2, it can be seen that $87.5 \%$ of the VIP latrines had no fly screens on vent pipes. This presupposes that, without any hindrance, pathogen-carrying flies can easily exit the pit via the vent pipes into the environment. Also, female flies within the immediate surroundings of the facility searching for a conducive location to lay eggs would be attracted by the odour emanating from the vent pipes, hence, increasing fly nuisance in the latrine cubicles. A high prevalence of flies was observed within the cubicles of all the 10 VIP latrines considered under this study. It was observed that, whereas the majority of the female users living in the immediate environs of the facility entered with a blouse and single sheet of cloth wrapped around their mid-section, their male counterpart took off their shirts and sometimes pair of trousers before entering the facility owing to the stench in the faciltiy.

A survey of the VIP facility locations revealed the predominance of open defecation. This revelation supports Kosoe and Osumanu (2018), and Obeng et al. (2015), who indicated that users of public sanitary facilities usually hang their clothes at the entrance of the facility to avoid the smell or engage in open defecation to avoid odour and fly nuisance. It was further observed that all the VIP facilities had high light levels within the superstructure. The facilities had openings at multiple sides in the upper section of the superstructure therefore, increasing the amount of light within the latrine. This is, however, inconsistent with fly nuisance control in VIP latrines. The high level of light could also account for the flies seen in the latrines. Thus, this observation agrees with Mara as cited by Obeng et al. (2019c), that flies are attracted by light, hence, the presence of flies in the cubicles could be as a result of light in the superstructure of the latrines. 


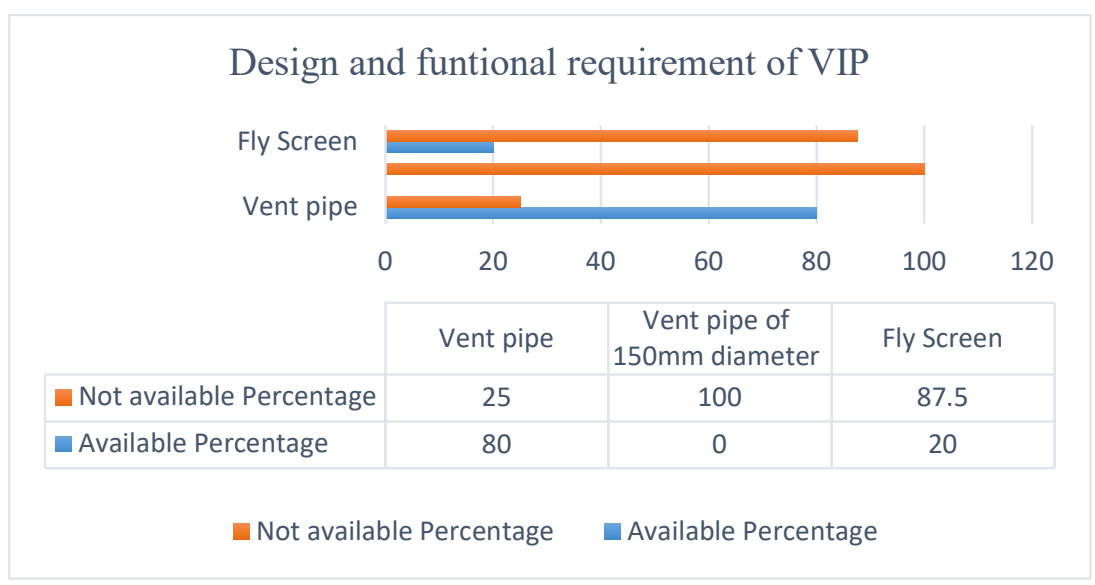

Figure 3: Design and functional requirement of VIP

This study also identified $15.9 \%$ of the public sanitary facilities to be WCs otherwise known as flush toilets. The study witnessed both sitting and squatting types of WCs in all 7 facilities. With the WC system, water is used to flush out the content (excreta) of the bowl or pan through a drain pipe into a septic tank. The solid part of the sewage settles in the first compartment, the liquid component then flows into the ensuing compartment where further settlement occurs. The effluent is then released to the drain field where organic materials in the liquid are broken down by microbes. This study revealed that $57.1 \%$ of the facilities had 2 compartment septic tanks and a drain field to receive the effluent from the second compartment. With the remaining $42.9 \%$, it was observed that each had septic tanks with three compartments for settlement of solids. Effluent from the third chamber drained into a chain of smaller chambers presumably designed to further screen and treat the effluent. The resultant effluent is then directly discharged into storm drains.

\subsubsection{Management systems and organisational structure of public toilets}

From the study, franchise and Build-Own-Operate (BOO) were the two options employed in the management of public toilets in Wa township. WMA owned $88.6 \%$ of the public toilet facilities. However, the Assembly has ceded out the operation and maintenance to Franchisees for a period of 2-3 years. The Franchisees pay a monthly franchise fee of GHs 30.00 per facility to the Assembly.

The WMA owned all $(\mathrm{n}=27)$ of the aqua privy and 9 of VIP latrines as well as $42.9 \%(\mathrm{n}=3)$ of the WC facilities (figure 3). The remaining $57.1 \%(\mathrm{n}=4)$ of the $\mathrm{WC}$ facilities were owned and operated by private investors under the BOO franchise arrangement. These private investors, however, pay GHs 120 to the Assembly every month.

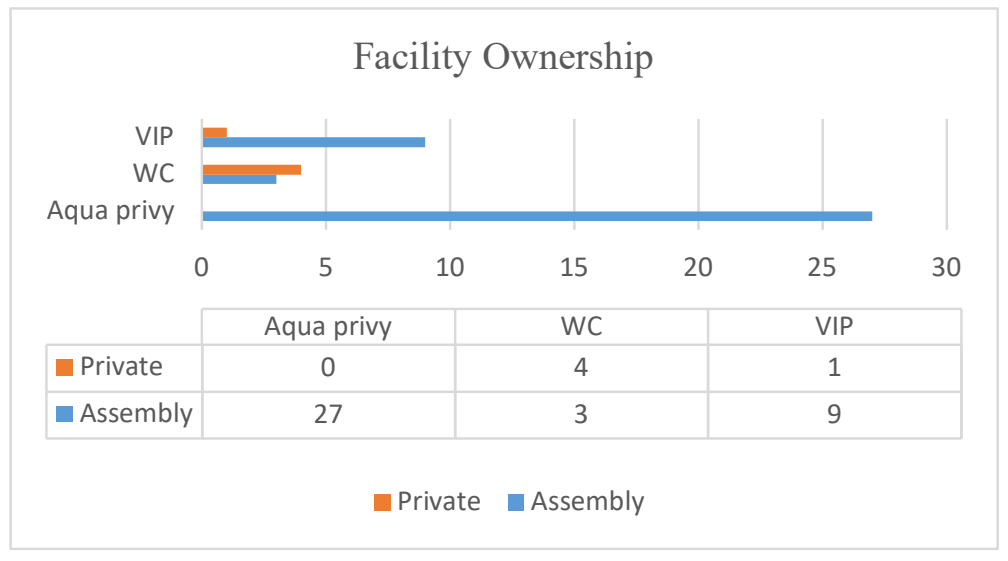

Figure 3: Ownership of sanitary facilities 
For a guaranteed satisfaction and quality service an Operator (Franchisee or private investor) employs and remunerated management staff depending on the capacity of facility, patronage, and duration of working hours. Table 2, presents a summary of the staffing situation in the facilities.

Most facility Operators reduced the required staff number to maximise profit. This resulted in ineffective supervision with an adverse trickle-down effect on other schedule officers in discharging their duties abysmally, hence, the low levels of sanitary conditions at the facilities. It is the responsibility of the Franchisees or Investors to ensure the safety of their staff. Consequently, employers are to ensure their staff undergo a mandatory biannual medical examination and also provide free treatment for all diseases relating to working in public toilets. The study, however, revealed that $91.1 \%$ of public toilet attendants (cleaners, revenue collectors, etc.) have never enjoyed this right and neither are they even aware of its existence.

Table 2: Staffing for operation and maintenance

\begin{tabular}{|c|c|c|}
\hline Management staff & Assembly owned facility & BOO facility \\
\hline Manager & Franchisee as Manager & Investor as Manager \\
\hline Supervisor & Franchisee as Supervisor & $\begin{array}{l}\text { Supervisor available or Investor as } \\
\text { Supervisor }\end{array}$ \\
\hline Finance Officer & Franchisee as Finance Officer & $\begin{array}{l}\text { Investor or Supervisors as Finance } \\
\text { Officers }\end{array}$ \\
\hline Cleaners & 1 in all facilities, no shift & 2 on the average, no shift \\
\hline Revenue Collectors & 1 in all facilities, no shifts & 1 on the average, no shift \\
\hline Artisans & As and when needed & As and when needed \\
\hline
\end{tabular}

\subsubsection{Cleaning of toilet facilities}

Effective cleaning of toilet facilities guarantees a hygienic environment thereby safeguarding the safety and wellbeing of the users. Per the study, all 42 functional public toilet facilities carried out interior cleaning daily. In order not to inconvenience users during peak hours, all (100\%) facilities carried out thorough cleaning at dawn before the commencement of daily operations. Analysis of the study data revealed that all (100\%) of the facilities undertook thorough cleaning once a day. However, except for $10.8 \%$ facilities that operated with one person as a cleaner and a revenue collector, all the other $89.2 \%$ facilities either carried out touch-up or spot cleaning during peak hours or at the discretion of the attendant. The scope of thorough cleaning and frequency of touch-up or spot cleaning was dependent on the availability of water, patronage, maintenance standard, and discretion of the cleaning attendant.

All the WC facilities had an adequate and regular on-site supply of freshwater which facilitated thorough cleaning and touch-up or spot cleaning of floors and sanitary wares daily or as and when required. Of the 7 WC facilities, $57.1 \%$ had mechanized boreholes connected to overhead tanks which in-turn supplied water to all point-of-use. The other 42.8 facilities were connected to the national grid. The study revealed that $66.7 \%$ of the WC facilities cleaned cubicle wall surfaces weekly and the remaining $33.3 \%$ cleaned fortnightly. The reason given was that adding the cleaning of wall surfaces to the regular daily cleaning schedule delayed time. It was observed that inappropriate usage of water for anal cleansing, squatting on the toilet bowl, soiling of the inner sides of the bowl, urinating on the floor instead of the toilet pan/bowl occasioned spot cleaning. For such reasons Bernama (2011), asserted that users of public toilets needed some level of insight in using the facility.

Generally, the sanitary conditions as observed in all aqua privy and VIP latrines facilities was inadequate. The non-availability of on-site water supply affected the output of the interior cleaning. Cleaning attendants bought water from private vendors to clean the facilities. This, therefore, limited the water available for effective cleaning. Drops of excreta were visibly seen around the squatting hole even after cleaning in the morning. The wall surfaces of the cubicles of all facilities were covered with faecal matter. The general sanitary conditions varied between facilities depending on the output of the cleaning attendant. The situation was awful at facilities where revenue collectors doubled as a cleaning attendant. These attendants are mostly preoccupied with revenue collection with 
little or no time for cleaning. This finding is in line with a study by Peprah et al. (2015), where they argued that the level of cleanliness in public toilet facilities is subjected to how operators empathise with users.

Cleaning agents such as liquid or powdered soap, disinfectants and, basic cleaning tools such as brooms, scrubbing brushes, mops were employed in removing excreta and to curb the infestation of cockroaches, flies, and maggot in the cubicles. The study revealed that where as $74.2 \%$ of the VIP and aqua privy facilities used raw water without any detergent or disinfectant in cleaning the remaining $25.8 \%$ however, used a very small amount of detergent in cleaning. Most (82.6\%) of the cleaning attendants have no formal education or in-service training in hygiene and therefore does not appreciate the effect of not using the appropriate proportion of detergent and disinfectants in cleaning toilet facilities and transmission of diseases. This finding validates Greed (2006), who asserts that unhealthy and unhygienic conditions of public toilets facilitate germ transmission. The study further revealed that institutional weakness contributed to the sorry state of the facilities since facility supervisors and Environmental Health Officers of the Municipal Assembly reneged on their duties. In sharp contrast, detergents and disinfectants were persistently used in cleaning the WC facilities. However, by physical observation, the level of cleanliness at the BOO facilities $(n=4)$ surpassed that of the Assembly franchised facilities $(n=3)$. The cleaning attendants at the BOO facilities attributed their work output to fear of dismissal by the employer. They indicated that any lapses in their output will lead to their dismissal because according to their employers unhealthy and unhygienic conditions will keep some users away from the facilities. This observation supports the opinion that unhealthy and unhygienic conditions of public toilets keep users away from using the facility (Akhter, 2013). It is worth noting that none of the cleaning attendants was seen in protective gear whilst working although a few pairs of wellington boots and hand gloves were seen on the premises of some facilities.

\subsubsection{Management of anal cleansing materials and Sludge}

From the study, users of the facilities had to choose between an old newspaper and tissue as an anal cleansing material depending on the technology of the facility. The WC facilities encouraged the use of tissue while the other facilities used either the old newspaper or tissue depending on the patron's preference or affordability. The use of water as an anal cleansing material was allowed in all facilities. Most all (92.1\%) facilities provided users with water for anal cleansing. Although, all the solid anal cleansing material provided by all facilities for use by users could be dumped in the drop hole or toilet bowl to join the sludge for eventual desludging, treatment, and disposal. The study revealed that waste bins were provided in almost all $(89.2 \%)$ the public toilet facilities.

The collected used anal cleansing materials are either burnt openly onsite or disposed of it in skip bins especially at facilities that double as refuse dumping site. The provision of waste bins violates the directives of the Management of Public Toilets Guidelines. According to the MLGRD (2003), anal cleansing materials should always be disposed of in the drop hole or, toilet bowls or pan because disposing of it in communal solid waste containers, or by burning in the open air, is highly insanitary.

The Environmental Health Unit of WMA and Urban Waste Ghana Limited (a subsidiary of Zoomlion Ghana Limited) were identified by this study as the only entities operating vacuum suction trucks for faecal sludge collection services on scheduled or on-request service basis. The rate of desludging depended on the capacity of the sludge tank and patronage of a facility. The cost of desludging ranged between GHs 120 and GHs 150 per trip depending on the type of facility. An interview with a vacuum truck driver revealed that desludging a septic tank was relatively easier as compared to a VIP or an aqua privy. He indicated that some users capitalised on the sizes of the drop-holes of the VIPs and aqua privies to dump plastics and other non-degradable solid materials into the tanks. This claim corroborates with the argument that, the physical properties and characteristics of latrine contents indicate the presence of degradable and non-degradable materials (Kabange and Nkansah, 2019). The presence of foreign materials and loss of fluid due to seepage leads to a buildup of very dense sludge which extends to the base of the tank. This revelation is in line with Brouckaert et al. (2013), who posits that some users have the habit of dropping substantial amounts of non-degradable waste into latrine pit which leads to premature fill-up of the pits. For easy suction of the sludge, water has to be added to loosen the very denser sludge. It was observed that $90.6 \%$ of the aqua privy and VIP facilities which were still in operation were filled up with maggots migrating from the pit to the surrounding subsurface. The unfortunate situation presents serious health threats for users of such facilities. The facility managers blamed the situation on unreliable faecal sludge drainage services by providers. The study, however, found that each service provider had one active vacuum suction truck. These two trucks rendered both domestic and public desludging services in the entire Municipality, hence their inability to immediately respond to the needs of the public toilet facilities. In addition, the service providers preferred desludging household toilet facilities to public toilet facilities because of its attendant issues. This affirms a recent study by Kosoe and Osumanu (2018), in the Wa Municipality where a vacuum truck driver described the desludging of public toilets as a daunting task. 
For a healthy and safe environment, fecal sludge must be appropriately processed at sludge treatment plants before disposal. The study uncovered that there is no treatment plant in Wa township and the faecal sludge disposal methods can best be described as very unhygienic. The Municipal Assembly has no sludge treatment plant or regulated dumpsite. This validates Kosoe and Osumsnu's (2018), findings and description of the situation as abysmal. The direct disposal of raw faecal sludge at nearby villages (notably Siiyiri, Junga, and Boli) or onto farmlands (especially just before the beginning of the farming season) were revealed as methods of raw faecal sludge disposal in the study area. This is associated with the affirmation of Impraim et at. (2014), that vacuum truck drivers discharged raw faecal sludge onto farmlands during the fallow period or dry season in the Northern part of Ghana.

\subsubsection{Rehabilitation and repairs}

The study noted that $47.9 \%$ of the facilities have not undergone any form of repair works in the last 7 years. The study further revealed that $11.4 \%$ of the facilities were recently renovated. Different degrees of defects were identified in some of the facilities. Whereas some of the defects affected the structural safety of the facilities others had no bearing on structural safety. Poor workmanship, inferior material, the lack of basic maintenance, aging, and natural deterioration were identified as some of the causes of the defects found in some of the public toilet facilities. Some defects in public toilet facilities identified by this study include spalling in plaster and concrete, peeling of paint, doors, roof covering, dampness, cracks in tanks, slabs, and walls.

\section{Conclusion and recommendation}

Public toilets are an important sanitation option that responds to the sanitary needs of the urban poor and transient populace. Three main sanitary technologies were identified by the study, this included aqua privy, water closet (WC), and ventilated improved pit (VIP) latrine. From the study, franchise and Build-Own-Operate (BOO) were the two options employed in the management of public toilets in Wa township. The results of this study indicated that sanitary conditions of most public toilet facilities in Wa township were in a sorry state and therefore need urgent improvement. Nonetheless, the conditions at the facilities managed under the BOO scheme appeared to be hygienic and acceptable than those managed under the franchise scheme. The findings of the study further suggest that poor supervision, lack of regular and adequate on-site water, lack of training on toilet management and maintenance has contributed to the sorry state of most toilet facilities. The physical state of some of the facilities especially those owned by WMA were found to be deplorable and needed rehabilitation. Raw faecal sludge from the facilities was disposed of onto farmlands and other uncontrolled sites.

This study recommends the resourcing and tooling of Environmental Health Officers of WMA for effective and intensive monitoring of the public toilet facilities to ensure operators comply with the guidelines for the provision, operation, and maintenance of public toilets by MLGRD. The study further recommends the establishment of a sludge treatment plant or a dedicated and regulated site for faecal sludge dumping.

\section{References}

Amoah, S.T. and Kosoe, E.A. (2014), "Solid waste management in urban areas of Ghana: Issues and experiences from Wa", Journal of Environment Pollution and Human Health, 2 (5), pp. 110-117.

Akhter, S. (2013), “The Importance of Public Toilet for Women Health”, The Financial Express Vol. 20 No 157 Regd No DA 1589 Dhaka, Monday, March 11. Retrieved from http//: www.thefinancialexpress-bd.com. Accessed on $21 / 03 / 2020$.

Arthur, D. D. (2017), "Interrogating the challenging pathways of decentralization of water and sanitation services delivery in the Wa Municipality of the Upper West Region of Ghana", UDS International Journal of Development [UDSIJD] ISSN: 2026-5336 Volume 4 No. 2, December, 2017 http://www.udsijd.org.

Ayee, J. and Crook, R. (2003), “Toilet wars: urban sanitation services and the politics of public-private partnerships in Ghana”, IDS Working Paper 213 December 2003

Bernama. (2011), “The Need to Keep Our Public Toilet Clean. Malaysian Digest”, Tuesday, 28 June. Retrieved from www.malaysiandigest.com/features/26058. Accessed on 21/03/2020

Brouckaert, C.J., Foxon, K.M. and Wood, K. (2013), "Modelling the filling rate of pit latrines", Water SA. 39(4), pp. 555-562. 
Cardone R,, Schrecongost A., and Gilsdorf R. (2018), "Shared and public Toilets: Championing delivery models that work", The World Bank Group, 1818 H Street NW, Washington, DC 20433, USA; worldbank.org.

Darimani, H. S., Kwofie J., Tuolong, J. G. (2020), “The assessment of heavy metals concentration in groundwater: a case study of the Wa Municipality", Environmental Management and Sustainable Development ISSN 2164-7682 2020, Vol. 9, No. 1

Greed, C. (2006), “The Role of the Public Toilet: Pathogen Transmitter or Health Facilitator”, Building Services Engineering and Research and Technology, May 2006 Vol. 27 No 2127-139.

Ghana Statistical Service (2012), “Ghana population and housing census 2010”, Synthesis report. Accra Ghana Statistical Service.

Ghana Statistical Service (2014), “Ghana living standards survey Round 6”, Accra: Ghana Statistical Service.

Impraim R., Josiane N., and Cofie O. (2014), "Value from faecal sludge and municipal organic waste: fertilizer cum soil conditioner in Ghana", $37^{\text {th }}$ WEDC International Conference, Hanoi, Vietnam,2014, Briefing Paper 2035

Kabange, R. S. and Nkansah, A. (2019), “A review of pit latrine emptying technologies for low-income denselyPopulated settlements of developing countries”, Current Trends in Civil \& Structural Engineering. ISSN: 26436876 DOI: 10.33552/CTCSE.2019.01.000510

Kosoe, E. A. and Osumanu I. K. (2018). "Entertaining Risks to Health: The State of Human Faecal Matter Managemnt in Wa", Ghana Ghana Journal of Development Studies, Vol. 15 (1)

McGinnis, S., Marini D., Amatya, P. and Murphy, H. M., (2019), "Bacterial Contamination on Latrine Surfaces in Community and Household Latrines in Kathmandu, Nepal", Int. J. Environ. Res. Public Health 2019, 16, 257

Ministry of Local Government and Rural Development (2013), "Guidelines for the Provision, Operation and Maintenance of Public Toilets", January 2003

Nelson, K. B., Karver, J., Kullman, C. and Graham J. P. (2014), “User perceptions of shared sanitation among rural households in Indonesia and Bangladesh”, PLoS ONE 9(8): e103886. doi: 10.1371/journal.pone.0103886

Obeng, P. A., Keraita, B., Oduro-Kwarteng, S., Bregnhøj, H., Abaidoo, R. C., Awuah, E. \& Konradsen, F. (2015), "Usage and barriers to use of latrines in a Ghanaian peri-urban community", Environmental Processes 2, 261274. doi: 10.1007/s40710- 015-0060-z.

Obeng, P. A., Oduro-Kwarteng, S., Keraita, B., Bregnhøj, H., Abaidoo, R. C., Awuah, E. \& Konradsen, F. (2019a), "Redesigning the ventilated improved pit latrine for use in built-up low-income settings", Journal of Water, Sanitation and Hygiene for Development 2(1), 261-274. doi: 10.2166/washdev.2019.098.

Obeng, P. A., Oduro-Kwarteng, S., Keraita, B., Bregnhøj, H., Abaidoo, R. C., Awuah, E. \& Konradsen, F. (2019b), "Optimising ventilation to control odour in the ventilated improved pit latrine", Modelling Earth Systems and Environment 5, 133-142. doi: 10.1007/s40808-018-0523-0

Obenga, P. A., Obeng, P. A., and Awereb, E. (2019c), "Design and construction of household ventilated improved pit latrines: gaps between conventional technical guidelines and construction practices in Cape Coast", Ghana. Water Practice \& Technology Vol 14 No 4 doi: 10.2166/wpt.2019.067

Okechukwu, O. I., Okechukwu, A. A., Noye-Nortey H., Owusu-Agyei (2012), "Toilet practices among the inhabitants of Kintampo District of Northern Ghana", Journal of Medicine and Medical Sciences Vol. 3(8) pp. 522-530, August 2012 Available online http://www.interesjournals.org/JMMS

Osumanu, I. K., Kosoe, E. A., and Ategeeng, F. (2019), “Determinants of Open Defecation in the Wa Municipality of Ghana: Empirical findings highlighting sociocultural and economic dynamics among households", Journal of Environmental and Public Health Volume 2019, Article ID 3075840, 10 pages https://doi.org/10.1155/2019/3075840 
Oyinloye, M. A. And Oluwadare, O. I. (2015), "Public conveniences and sanitation challenges in developing nations: A focus on Agege, Lagos, Nigeria", International Journal of Research in Social Sciences. Sept. 2015. Vol. 5, No.7 ISSN 2307-227X

Peprah, D., Baker, K. K., Moe, C. Robb K., Wellington, N., Yakubu, H. and Null, C. (2015), "Public toilets and their customers in low-income Accra, Ghana", International Institute for Environment and Development (IIED). Vol 27(2): 589-604. DOI: 10.1177/0956247815595918 www.sagepublications.com

Ruiz, N. S. and Kaiser, A. M. (2017), "Faecal incontinence - Challenges and solutions", World J Gastroenterol 2017 January 7; 23(1): 11-24 ISSN 1007-9327 (print) ISSN 2219-2840 (online)

Reed, B. (2011), "Septic Tank and Aqua Privy Design", Developing knowledge and capacity in water and sanitation, Guide 30 WEDC, Loughborough University, 2011

Reed, B. (2014), "Ventilated Improved Pit (VIP) Latrines", Developing knowledge and capacity in water and sanitation, Guide 27 WEDC, Loughborough University, 2014

World Health Organization (2018), “Guidelines on sanitation and health”, Geneva: World Health Organization; 2018. Licence: CC BY-NC-SA 3.0 IGO. ISBN 978-92-4-151470-5

WHO/UNICEF/JMP (2019), "Progress on household drinking water, sanitation and hygiene 2000-2017: Special focus on inequalities", ISBN: 978-92-806-5036-5

WHO/UNICEF/JMP (2015b), "WASH Post-2015: Proposed indicators for drinking water, sanitation and hygiene", Briefing note. Geneva, Switzerland. 